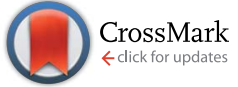

Cite this: RSC Adv., 2017, 7, 13498

Received 5th November 2016 Accepted 24th January 2017

DOI: $10.1039 / c 6 r a 26340 b$

rsc.li/rsc-advances

\section{Effects of graphene oxide on the geopolymerization mechanism determined by quenching the reaction at intermediate states}

\author{
Shu Yan, $\dagger^{\text {ac }}$ Peigang He, $\dagger^{* a c}$ Dechang Jia, ${ }^{\text {*abc }}$ Xiaoming Duan, ${ }^{\text {abc }}$ Zhihua Yang, ${ }^{\text {abc }}$ \\ Shengjin Wang ${ }^{\text {ac }}$ and $Y u Z_{\text {Zhou }}^{\text {ab }}$
}

The effects of graphene oxide on the geopolymerization reaction products at different times were investigated by quenching the reaction. The phase composition and valence bond structure evolution were investigated systematically. The results show that the ethanol/acetone mixture helps isolate reaction products early in the process $(0-24 \mathrm{~h})$. RGO bonded well with the geopolymer matrix during the geopolymerization. The degree of densification increased and the amorphous nature of the material decreased with reaction time. The addition of $\mathrm{rGO}$ accelerated the conversion of five and six coordinate $\mathrm{Al}-\mathrm{O}$ sites into four coordinates and $\mathrm{Si}$ atoms forming $\mathrm{Q}_{4}(3 \mathrm{Al})$ network structure.

\section{Introduction}

Geopolymers are a class of aluminosilicate materials that have attracted considerable industrial attention as they offer a combination of low densities, low costs, easy processing and environmentally friendly materials..$^{1-5}$ Geopolymers are synthesized by dissolution of aluminosilicates under highly alkaline conditions, as initially described by Davidovits. ${ }^{\mathbf{1 , 2}}$ Compared with portland cement, geopolymer slurries can transform to solid state materials after proper setting with better mechanical properties. ${ }^{6,7}$ However, low strength and brittle nature of geopolymers could not meet the needs in industrial applications. ${ }^{8}$ Thus, geopolymers composites were produced using particles $^{9,10}$ and fibers ${ }^{11-14}$ to overcome the disadvantages.

Graphene attracted great interests for its excellent properties (e.g., high specific surface area, unusual thermal, electrical, optical and mechanical properties). ${ }^{15-17}$ As a new nano filler material, it provided considerable potential in the fabrication of multifunctional polymers and ceramic matrix composites. ${ }^{\mathbf{1 8 - 2 0}}$ In our previous works, ${ }^{\mathbf{9}, \mathbf{1 2 , 1 3 , 2 1 - 2 5}}$ we have investigated $\mathrm{Al}_{2} \mathrm{O}_{3},{ }^{\text {, }}$ cenospheres, $^{21}$ carbon fibers ${ }^{\mathbf{1 2 , 1 3}}$ and graphene oxide (GO) ${ }^{\mathbf{2 2 - 2 5}}$ reinforced geopolymer composites. However, the effects of graphene oxide addition on the geopolymerization mechanism

${ }^{a}$ Institute for Advanced Ceramics, Harbin Institute of Technology, Harbin 150080, China

${ }^{b}$ State Key Laboratory of Advanced Welding and Joining, Harbin Institute of Technology, Harbin 150001, Heilongijang, China

${ }^{c}$ School of Materials Science and Engineering, Harbin Institute of Technology, P. O. Box 433, Harbin 150080, China. E-mail: peiganghe@hit.edu.cn; dcjia@hit.edu.cn; Fax: +860451 86414291; Tel: +86045186418792

$\dagger$ Co-first authors, these authors contributed equally to this study and share first authorship. of the $\mathrm{rGO} / \mathrm{g}$ eopolymer ( $\mathrm{rGO} / \mathrm{KGP}$ ) during the processing was also not been investigated.

Like cements, much work has been done to study on geopolymerization including theoretical modeling and water removal techniques. ${ }^{26-34}$ Thus, Xu et $a .^{27}$ used five-membered alumino-silicate framework ring models in $A b$ initio calculations. Weng et al. ${ }^{29,30}$ compared the hydrolysis and condensation reactions between low and high $\mathrm{Si} / \mathrm{Al}$ ratio geopolymers. The partial charge model predictions and experimental results suggested possible $\mathrm{Al}$ and $\mathrm{Si}$ monomeric species that might form during the dissolution and condensation process. Mitchell et al. ${ }^{34}$ reported that polar solvents (acetone or isopropyl alcohol) could help to stop hydration reactions. But aldol reactions can occur by the presence of $\nu \mathrm{C}-\mathrm{H}$ during the derivative thermo gravimetric analysis of the reaction products. Chen et al. ${ }^{31}$ demonstrated a solvent extraction method using a mixture of alcohol and acetone to stop the reaction and acquire samples for nuclear magnetic resonance (NMR) studies. Unfortunately, a detailed understanding of the entire process remains largely elusive.

Since the reaction products of geopolymers depended highly on the raw material, alkali-activated solution and curing conditions, ${ }^{32}$ the structure changes in the geopolymer matrix used have not been quantitatively characterized especially in the early stages during the geopolymerization process. The reaction products often have considerable water, that interferes with characterization tools, such as Nuclear Magnetic Resonance (NMR) and X-ray diffraction (XRD). Thus, it is quite necessary to develop a method of arresting reaction during the geopolymerization process.

In the present work, we describe such a method and thereafter systematically characterize the effects of graphene oxide on the initial products using micrographs, phase composition, functional group and valence bond structure evolution. 


\section{Experimental}

\subsection{Materials}

GO powders (Nanjing XFNANO Materials Tech Co., Ltd., Nanjing, China), kaolin (95\%, Fengxian Reagent Factory, China), silica sol (40 wt\%, Jiangsu Xiagang, Indus, China) and $\mathrm{KOH}$ (85\%, Tianjin Guangfu Indus., China) were used as starting materials. The metakaolin used for synthesis of geopolymer were obtained from heat treated kaolin at $800{ }^{\circ} \mathrm{C}$ for $2 \mathrm{~h}$ in air. GO dispersion solutions with the concentration of $16.7 \mathrm{mg}$ $\mathrm{mL}^{-1}$ were prepared by ultrasonically dispersing GO powders in distilled water for $6 \mathrm{~h}^{22}$ The geopolymer had the following proportions: $\mathrm{SiO}_{2} / \mathrm{Al}_{2} \mathrm{O}_{3}=4.0, \mathrm{~K}_{2} \mathrm{O} / \mathrm{SiO}_{2}=0.25$ and $\mathrm{H}_{2} \mathrm{O} / \mathrm{K}_{2} \mathrm{O}=$ 15 (mole ratio). ${ }^{35,36}$

\subsection{Preparation of reaction products}

The alkaline mixture was synthesized by mixing silica sol with $\mathrm{KOH}$ for 3 days with the help of magnetic stirring. The rGO/ geopolymeric alkaline mixture (GO powders/metakaolin 1 $\mathrm{wt} \%$ ) was prepared by dropping the obtained GO dispersion to the alkaline mixture and stirred for $15 \mathrm{~min}$. Thereafter, the rGO/ geopolymer slurry was prepared by adding the metakaolin powders into the alkaline mixture and mixing for $45 \mathrm{~min}$ using a high-shear mixer and ultrasonication in an ice bath. The continuous stirring under ice bath ensured complete distribution and fully dissolution of both metakaolin particles and rGO powders resulting in a low viscosity, homogeneous slurry. Then, the slurry was casted in plastic containers and cured at $60{ }^{\circ} \mathrm{C}$ for different times $(0-24 \mathrm{~h})$ to get the reaction products.

In order to remove water, some preliminary preparations were carried out. Slurry samples (if they had not set, $0-2 \mathrm{~h}$ ) were directly added into a 50/50 ( $\mathrm{vol}$ ) ethanol/acetone mixture and stirred hard for round $5 \mathrm{~min}$ (around $1 \mathrm{~g}$ samples and $100 \mathrm{~mL}$ ethanol/acetone mixture), then continued adding new solvent. This procedure was repeated for three times, until the reaction products became particles. Samples (if they had set, 3-24 h) were first divided into micron-sized particles using a mortar and

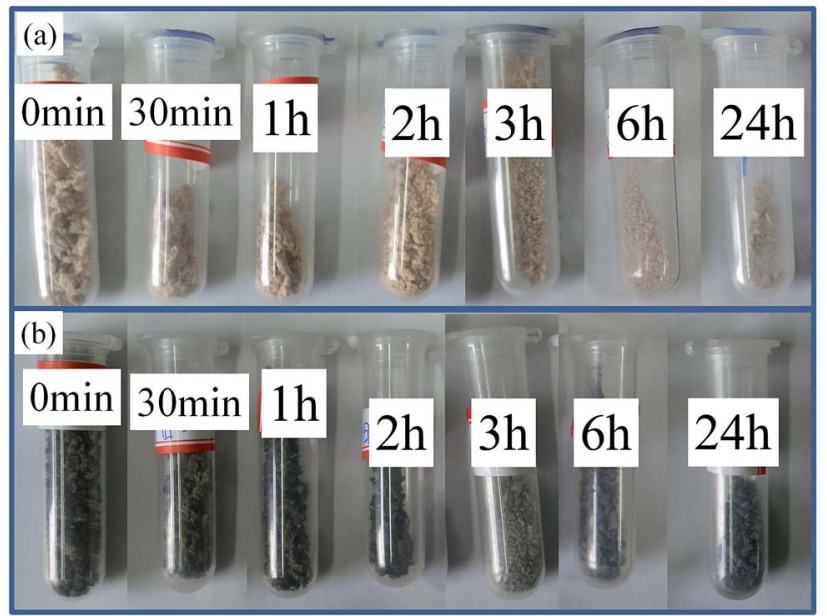

Fig. 1 Photographs of (a) KGP and (b) rGO/KGP samples obtained at different reacting time.
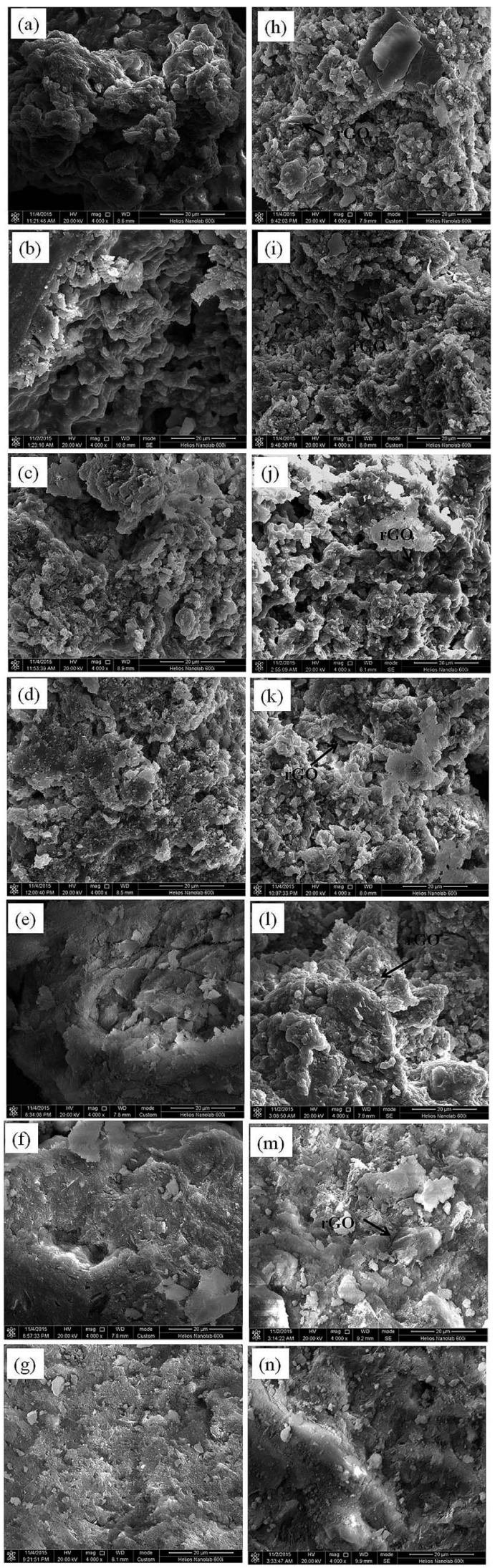

Fig. 2 Micrographs of the reaction products of $(\mathrm{a})-(\mathrm{g})$ KGP and $(\mathrm{h})-(\mathrm{n})$ rGO/KGP formed at various reaction times in geopolymerization process: (a) $-(\mathrm{g})$ and $(\mathrm{h})-(\mathrm{n})$ corresponding to $0 \mathrm{~min}, 30 \mathrm{~min}, 1 \mathrm{~h}, 2 \mathrm{~h}$, $3 \mathrm{~h}, 6 \mathrm{~h}$, and $24 \mathrm{~h}$ respectively. 

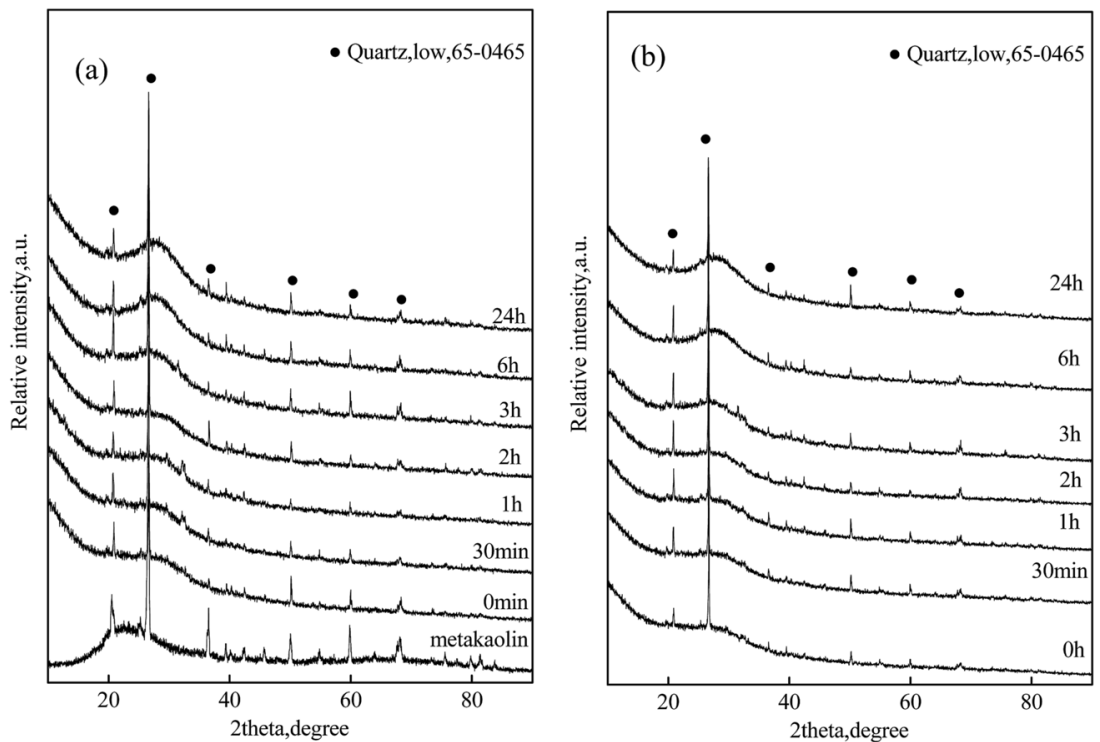

Fig. 3 XRD patterns of the reaction products of (a) KGP and (b) rGO/KGP formed at various reaction times in geopolymerization process.

pestle, and then mixed with 50/50 (vol) ethanol/acetone mixture for round 5 min to remove water. Then, taking out and drying the particle samples at room temperature, as can be seen in Fig. 1. Finally, use a mortar and pestle to grind the samples for characterization.

\subsection{Characterization}

The micrographs of the geopolymer (KGP) and rGO/geopolymer (rGO/KGP) reaction products were observed using scanning electron microscope (SEM, FEI, Helios NanoLab 600i). Fouriertransform infrared (FT-IR) spectra of raw kaolin, metakaolin

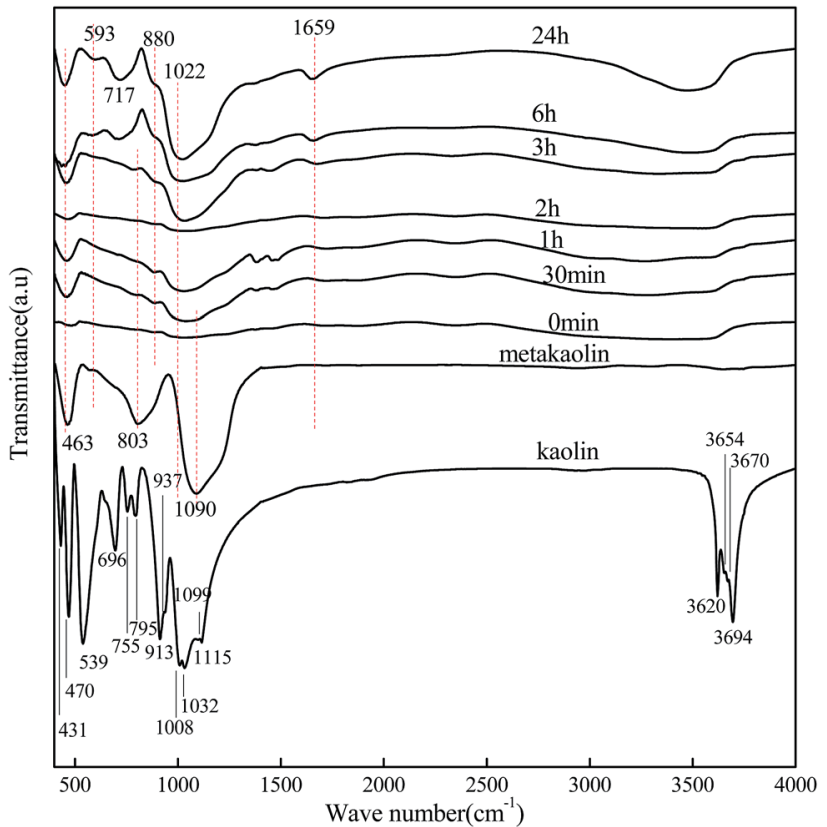

Fig. 4 FT-IR spectras of kaolin, metakaolin and reaction products of KGP formed at various reaction times in geopolymerization process. and reaction products during geopolymerization were obtained on a Nicolet Nexus 6700 Fourier transform infrared spectrometer. The phase compositions of the reaction products were examined by X-ray diffraction (XRD, Rigaku, RINT-2000) with $\mathrm{Cu}-\mathrm{K} \alpha$ radiation. The ${ }^{27} \mathrm{Al}$ and ${ }^{29} \mathrm{Si}$ solid state NMR were conducted using Bruker Avance III400 spectrometer with a magnetic field strength of $9.4 \mathrm{~T}$ and $4 \mathrm{~mm}$ rotor. The relaxation delay times were 2 and $1 \mathrm{~s}$ for ${ }^{27} \mathrm{Al}$ and ${ }^{29} \mathrm{Si}$ NMR spectra, respectively. The spectrometers were $5 \mathrm{kHz}$ for $\mathrm{Al}$ and $12 \mathrm{kHz}$ for Si. The chemical shifts of ${ }^{27} \mathrm{Al}$ and ${ }^{29} \mathrm{Si}$ nuclei were referenced to $\mathrm{AlNO}_{3}$ and tetramethylsilane, respectively.

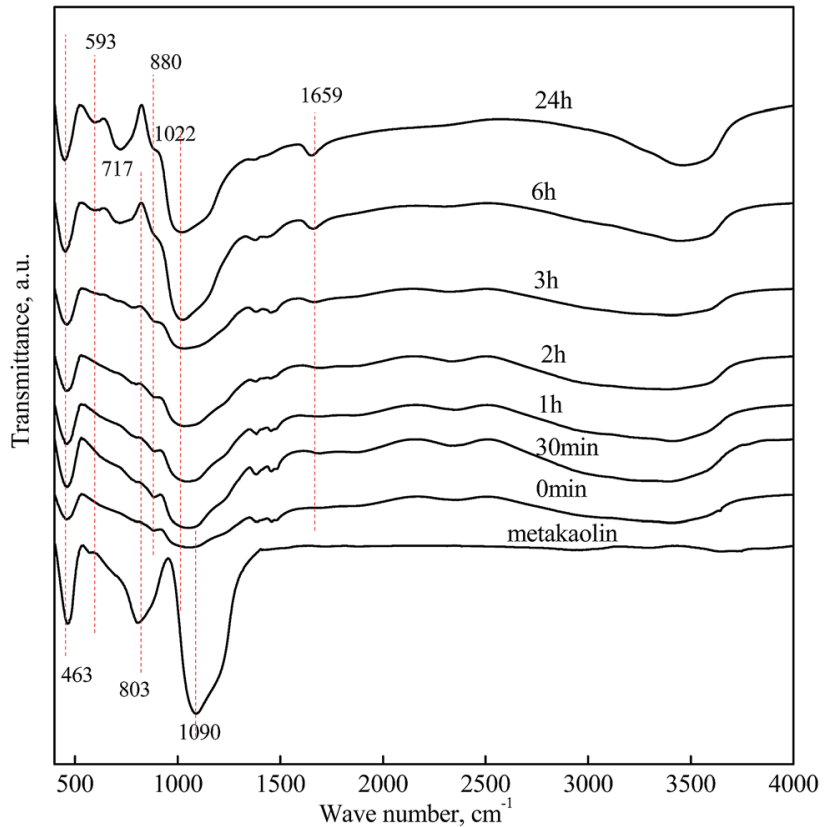

Fig. 5 FT-IR spectras of metakaolin and reaction products of $\mathrm{rGO}$ / KGP formed at various reaction times in geopolymerization process. 

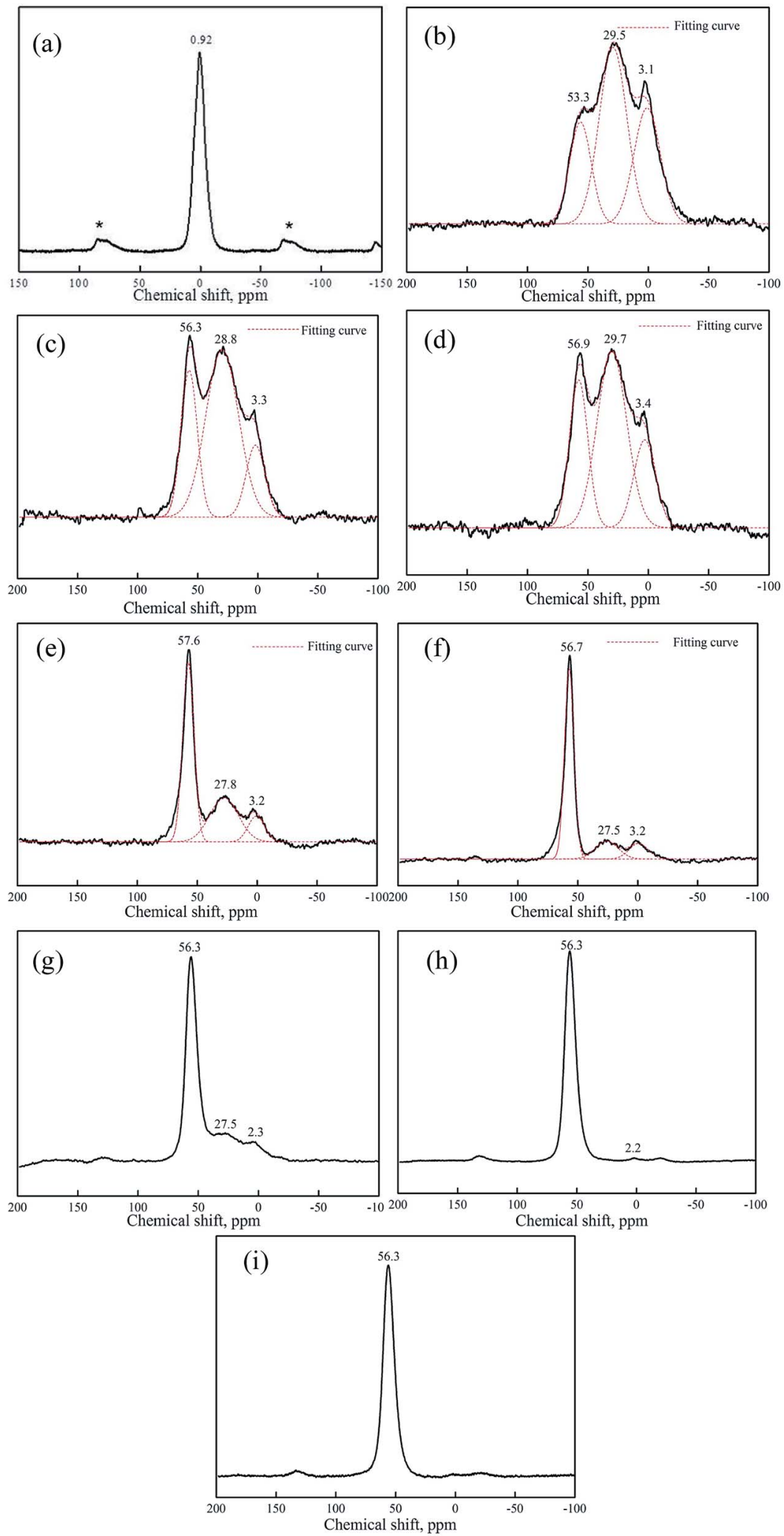

Fig. $6{ }^{27} \mathrm{Al}$ NMR spectras of kaolin and reaction product of KGP formed at various reaction times in geopolymerization process: (a)-(i) corresponding to kaolin, metakaolin, $0 \mathrm{~min}, 30 \mathrm{~min}, 1 \mathrm{~h}, 2 \mathrm{~h}, 3 \mathrm{~h}, 6 \mathrm{~h}$ and $24 \mathrm{~h}$, respectively. 


\section{Results and discussions}

Micrographs of particles for reaction products of both the KGP and $\mathrm{rGO} / \mathrm{KGP}$ samples formed at various reaction times are shown in Fig. 2. After stirring for $45 \mathrm{~min}$, the reaction products exhibit a porous and spongy morphology, with many irregular surface voids (Fig. 2(a) and (h)). The rGO bonded well with the reaction products of KGP matrix. The voids decreased significantly as time increased. At $3 \mathrm{~h}$, the reaction products became dense, without obvious voids (Fig. 2(e) and (l)). It could be found that the rGO was wrapped around by the particles of KGP matrix. After $24 \mathrm{~h}$, both the KGP and rGO/KGP offers a relatively homogeneous and dense microstructure (Fig. 2(g) and (n)).

Fig. 3 shows XRDs of the KGP and rGO/KGP products formed at various times. There was no obvious difference between the
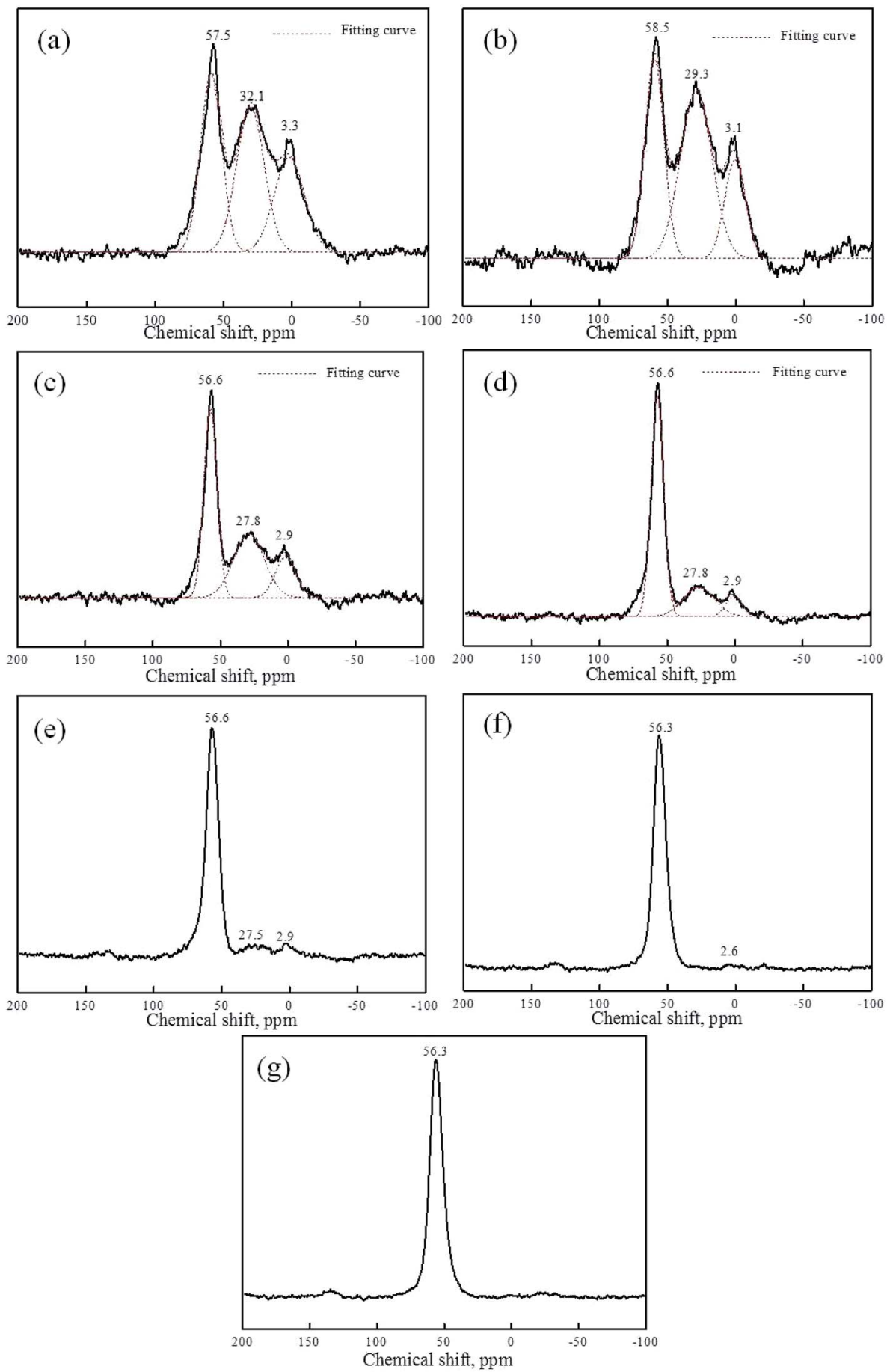

Fig. $7{ }^{27} \mathrm{Al}$ NMR spectras of reaction product of $\mathrm{rGO} / \mathrm{KGP}$ formed at various reaction times in geopolymerization process: (a)-(g) corresponding 0 min, 30 min, 1 h, 2 h, 3 h, 6 h and 24 h, respectively. 
two type samples. The patterns samples displayed typical geopolymer broad amorphous humps around $17-32^{\circ} 2 \theta$. The amorphous content decreased with the reaction time. The minor $\alpha$-quartz remained.

Fig. 4 and 5 show the FT-IR spectra of kaolin, metakaolin and reaction products of KGP and $\mathrm{rGO} / \mathrm{KGP}$ formed at various reaction times. As for the kaolin samples in Fig. 4, the bands at $3694,3670,3654$ and $3620 \mathrm{~cm}^{-1}$ are associated with $\nu \mathrm{O}-\mathrm{H}$ in

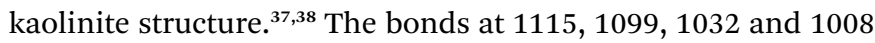
$\mathrm{cm}^{-1}$ corresponded to $\nu \mathrm{Si}-\mathrm{O}$ from $\mathrm{SiO}_{4}$. Sharp bands located at 937 and $913 \mathrm{~cm}^{-1}$ were attributed to $\nu \mathrm{Al}-\mathrm{OH}$ vibrations. ${ }^{38}$ The IR peaks at 795 and $755 \mathrm{~cm}^{-1}$ are assigned to $\nu \mathrm{Si}-\mathrm{O}-\mathrm{Al}$. The bands located at 696, 539 and $470 \mathrm{~cm}^{-1}$ was attributed to the $\mathrm{Si}-\mathrm{O}, \mathrm{Si}-$ $\mathrm{O}-\mathrm{Al}$ and $\mathrm{Si}-\mathrm{O}$ vibrations from $\mathrm{AlO}_{6}$, respectively. ${ }^{39}$ After treating at $800{ }^{\circ} \mathrm{C}$ for $2 \mathrm{~h}$, the transformation to metakaolin removes most of these bands, leaving three obvious peaks located at 1090, 803 and $463 \mathrm{~cm}^{-1}$, which attributed to the $\nu \mathrm{Si}-\mathrm{O}$ from $\mathrm{SiO}_{4}, \nu \mathrm{Al}-\mathrm{O}$ from $\mathrm{AlO}_{4}$ and $\mathrm{Si}-\mathrm{O}$ vibrations, respectively. It can be concluded that the $\mathrm{Si}-\mathrm{O}$ and $\mathrm{Al}-\mathrm{O}$ bonds hydrolyze during geopolymerization. ${ }^{32}$

The FT-IR spectras during geopolymerization over $24 \mathrm{~h}$ are also shown in Fig. 4 and 5. There was no obvious difference between the FT-IR spectra of the KGP with and without rGO. The bands positioned at 3500 and $1659 \mathrm{~cm}^{-1}$ were attributed to $\nu \mathrm{O}-\mathrm{H}$, indicating that adsorbed atmospheric water existed in the molded geopolymer sample. ${ }^{40}$ The intensity of the band located at $463 \mathrm{~cm}^{-1}$ increased with reaction time, suggesting formation of a greater number of Si-O-Si units. At $6 \mathrm{~h}$, the intensity of the bands at 593 and $717 \mathrm{~cm}^{-1}$ increased, related to increases in $\mathrm{Si}-\mathrm{O}-\mathrm{Al}$ and the four-coordinated $\mathrm{AlO}_{4}$ structure units in the reaction product. These represent the structural changes and rearrangement occurring during geopolymerization of Al units. Different from the FT-IR spectrum of the metakaolin, a weak shoulder located at $880 \mathrm{~cm}^{-1}$ appeared and increased with time, which was corresponding to the carbonate from atmospheric air.

The intense band related to $\nu \mathrm{Si}-\mathrm{O}$ shifts from 1090 to 1022 $\mathrm{cm}^{-1}$ after $24 \mathrm{~h}$, caused by the presence of Al-O bonds owing to silicon substitution by aluminum in the second coordination sphere and the generation of the $\mathrm{Si}(\mathrm{Al})-\mathrm{O}$ units. ${ }^{\mathbf{4 1}}$ The $\mathrm{Al}-\mathrm{O}$ band at $803 \mathrm{~cm}^{-1}$ decreases with the reaction time and disappears after $6 \mathrm{~h}$, confirming the dissolution of metakaolin and the disruption of the $\mathrm{Al}$ environment during the geopolymerization process.

It is difficult to distinguish the characteristic rGO peaks from the FT-IR spectra of the $\mathrm{rGO} / \mathrm{KGP}$ products due to their small content. Further influence of rGO on the reaction products could be detected by the ${ }^{27} \mathrm{Al}$ and ${ }^{29} \mathrm{Si}$ solid state NMR.

Fig. 6, 7 and Table 1 show the ${ }^{27} \mathrm{Al}$ NMR spectra and the Gaussian fit of raw kaolin, metakaolin and reaction products of KGP and $\mathrm{rGO} / \mathrm{KGP}$ formed at various times. As shown in Fig. 6(a), the ${ }^{27} \mathrm{Al}$ chemical shift of raw kaolin is $0.92 \mathrm{ppm}$, corresponding to six-coordinated aluminum. The three peaks at 53.3, 29.5 and $3.1 \mathrm{ppm}$ in the ${ }^{27} \mathrm{Al}$ NMR spectrum of metakaolin Fig. 6(b), can be attributed to 4-, 5- and 6-coordinate Al. The 5 -coordination accounts for $48 \%$ of total $\mathrm{Al}$ atoms, the major species in metakaolin.
The broad peaks arise due to highly distorted geometry at aluminum sites. ${ }^{32}$ After metakaolin reacts with alkaline solution for 0-30 $\mathrm{min}$, the $\mathrm{Al}$ coordination states of both the KGP (Fig. 6(c) and (d)) and the rGO/KGP (Fig. 7(a) and (b)) show no obvious change. The three peaks in the ${ }^{27} \mathrm{Al}$ NMR spectrum were attributed to 4-, 5- and 6-coordinate $\mathrm{Al}$. The 4-coordinate $\mathrm{Al}$ in the reaction products of $\mathrm{rGO} / \mathrm{KGP}$ was relatively more than the KGP matrix (Table 1), which may be attributed to the acceleration of rGO on the initial products early in the geopolymerization process.

The 5- and 6-coordinated $\mathrm{Al}$ atoms in the KGP samples appear to transform to 4 coordination gradually during geopolymerization over 1-3 h. The relative content of 4-coordinated $\mathrm{Al}$ atoms increased to $71.7 \%$ within $2 \mathrm{~h}$ (Fig. 6(f)). However, as for the $\mathrm{rGO} / \mathrm{KGP}$ samples, the relative content of 4-, 5- and 6coordinate $\mathrm{Al}$ atoms was $46.8 \%, 37.5 \%$ and $15.7 \%$ within $1 \mathrm{~h}$, respectively (Table 1 ). The species of the $\mathrm{Al}$ atoms were not changed, whereas, the 4-coordinated $\mathrm{Al}$ atoms increased to $69.8 \%$ within $2 \mathrm{~h}$ (Fig. 7 (d)). When the reaction time was longer than $3 \mathrm{~h}$, the 4-coordinated $\mathrm{Al}$ atoms (56.6 ppm) became the mainly species (Fig. 7(e)). However, at the same time, the fivecoordinated $\mathrm{Al}$ in the KGP and $\mathrm{rGO} / \mathrm{KGP}$ products was disappeared after $6 \mathrm{~h}$ (Fig. $6(\mathrm{~h})$ and $7(\mathrm{f})$ ).

After $24 \mathrm{~h}$, the peaks of both the KGP and rGO/KGP products at 56.3 ppm became sharper, indicating the coordination of $\mathrm{Al}-$ $\mathrm{O}$ in final geopolymer converts to four coordinate (Fig. 6(i) and $7(\mathrm{~g})$ ). The shift to 4-coordinated $\mathrm{Al}$ (from 53.3 to $56.3 \mathrm{ppm}$ ) likely arises because of extensive formation of $\mathrm{Si}-\mathrm{O}-\mathrm{Al}$ links. ${ }^{29,32}$

Table 1 Gaussian fit results of ${ }^{27} \mathrm{Al}$ NMR spectra of reaction products formed at various reaction times

\begin{tabular}{|c|c|c|c|c|c|c|c|c|}
\hline \multirow{4}{*}{$\begin{array}{l}\text { Sample } \\
\text { MK }\end{array}$} & \multicolumn{2}{|c|}{$\begin{array}{l}\text { Coordination } \\
\text { of } \mathrm{Al} \text { atom }\end{array}$} & \multicolumn{3}{|c|}{$\begin{array}{l}\text { Chemical shift } \\
(\mathrm{ppm})\end{array}$} & $\begin{array}{l}\text { Relative } \\
\text { area }\end{array}$ & \multicolumn{2}{|c|}{$\begin{array}{l}\text { Percentage } \\
(\%)\end{array}$} \\
\hline & \multicolumn{2}{|l|}{4} & \multicolumn{2}{|c|}{53.3} & & 2.37 & \multicolumn{2}{|c|}{21.6} \\
\hline & \multicolumn{2}{|l|}{5} & \multicolumn{2}{|c|}{29.5} & & 5.28 & \multicolumn{2}{|c|}{48.3} \\
\hline & \multicolumn{2}{|l|}{6} & \multicolumn{2}{|c|}{3.1} & & 3.29 & \multicolumn{2}{|c|}{30.1} \\
\hline & KGP & $\begin{array}{l}\mathrm{rGO} / \\
\mathrm{KGP}\end{array}$ & KGP & $\begin{array}{l}\mathrm{rGO} / \\
\mathrm{KGP}\end{array}$ & KGP & $\begin{array}{l}\mathrm{rGO} / \\
\mathrm{KGP}\end{array}$ & KGP & $\begin{array}{l}\mathrm{rGO} / \\
\mathrm{KGP}\end{array}$ \\
\hline \multirow[t]{3}{*}{$0 \mathrm{~min}$} & 4 & 4 & 56.3 & 57.5 & 3.06 & 3.16 & 25.8 & 35.2 \\
\hline & 5 & 5 & 28.8 & 32.1 & 7.09 & 3.41 & 59.6 & 37.8 \\
\hline & 6 & 6 & 3.3 & 3.3 & 1.73 & 2.43 & 14.6 & 27.0 \\
\hline \multirow[t]{3}{*}{$30 \mathrm{~min}$} & 4 & 4 & 56.9 & 58.5 & 5.86 & 2.25 & 27.6 & 34.3 \\
\hline & 5 & 5 & 29.7 & 29.3 & 11.28 & 3.13 & 53.1 & 47.6 \\
\hline & 6 & 6 & 3.4 & 3.1 & 4.10 & 1.19 & 19.3 & 18.1 \\
\hline \multirow[t]{3}{*}{$1 \mathrm{~h}$} & 4 & 4 & 57.6 & 56.6 & 2.41 & 2.33 & 54.3 & 46.8 \\
\hline & 5 & 5 & 27.8 & 27.8 & 1.52 & 1.87 & 34.2 & 37.5 \\
\hline & 6 & 6 & 3.2 & 2.9 & 0.51 & 0.78 & 11.5 & 15.7 \\
\hline \multirow[t]{3}{*}{$2 \mathrm{~h}$} & 4 & 4 & 56.7 & 56.6 & 3.61 & 4.34 & 71.7 & 69.8 \\
\hline & 5 & 5 & 27.5 & 27.8 & 0.82 & 1.39 & 16.5 & 22.3 \\
\hline & 6 & 6 & 3.2 & 2.9 & 0.60 & 0.49 & 11.8 & 7.9 \\
\hline \multirow[t]{3}{*}{$3 \mathrm{~h}$} & 4 & 4 & 56.3 & 56.6 & - & - & - & - \\
\hline & 5 & 5 & 27.5 & 27.5 & - & - & - & - \\
\hline & 6 & 6 & $\sim 2.3$ & 2.9 & - & - & - & - \\
\hline \multirow[t]{2}{*}{$6 \mathrm{~h}$} & 4 & 4 & 56.3 & 56.3 & 10 & 10 & 100 & 100 \\
\hline & 6 & 6 & $\sim 2.2$ & 2.6 & - & - & - & - \\
\hline $24 \mathrm{~h}$ & 4 & 4 & 56.3 & 56.3 & 10 & 10 & 100 & 100 \\
\hline
\end{tabular}


Compared with the KGP matrix products, the addition of rGO accelerated the conversion of 4-coordinated $\mathrm{Al}$ in the $\mathrm{rGO} / \mathrm{KGP}$ products at the early stage $(0-30 \quad \mathrm{~min})$ during the geopolymerization process. While, the effects of rGO was not obvious at the later stage (1-24 h). This was due to the KGP particles likely priority formed, attached and grown on the
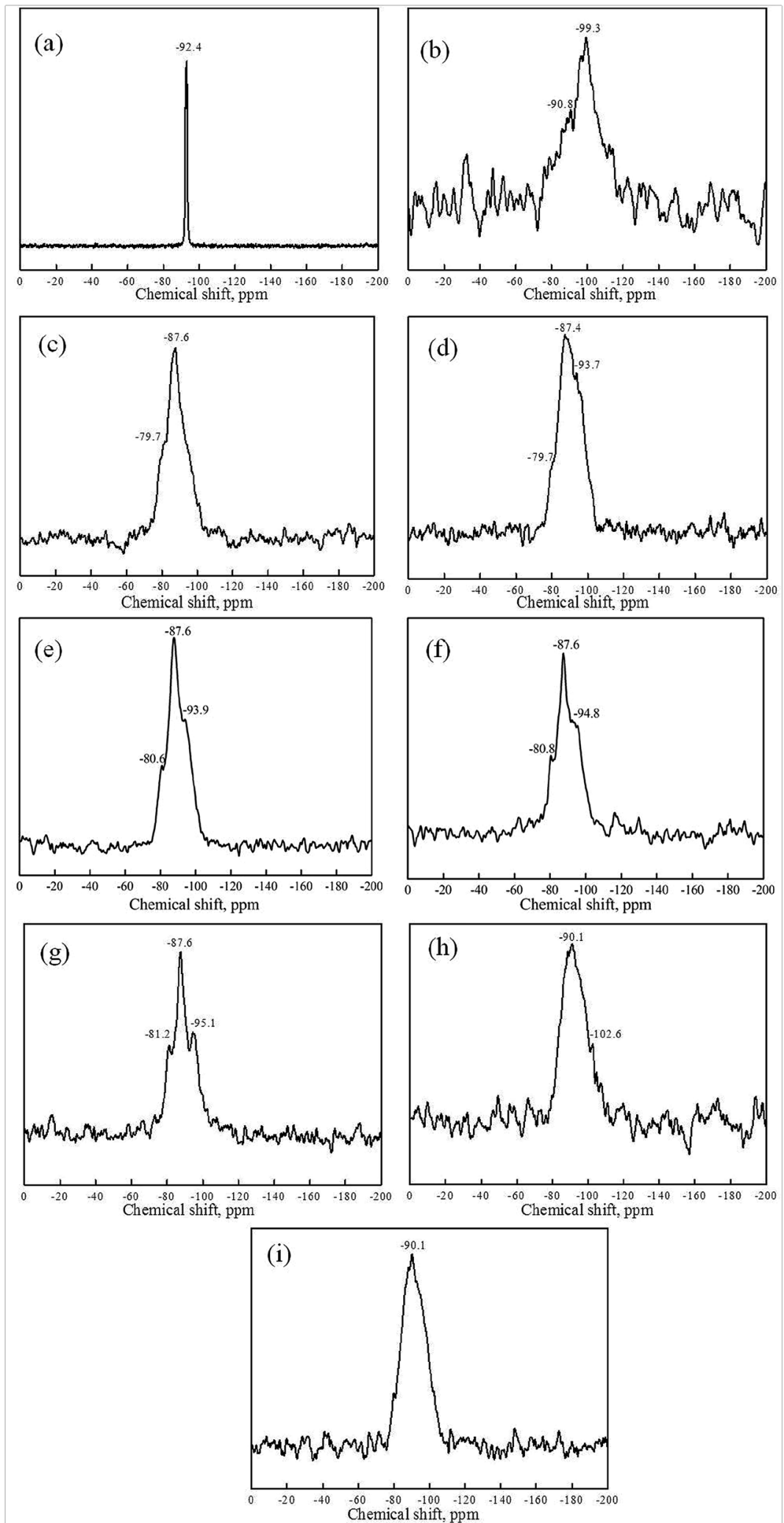

Fig. $8{ }^{29}$ Si NMR spectras of kaolin and reaction product of KGP formed at various reaction times in geopolymerization process: (a)-(i) corresponding to kaolin, metakaolin, 0 min, $30 \mathrm{~min}, 1 \mathrm{~h}, 2 \mathrm{~h}, 3 \mathrm{~h}, 6 \mathrm{~h}$ and $24 \mathrm{~h}$, respectively. 
surface of the rGO sheets. However, the geopolymer matrix was solidificated, surface of the rGO was all parceled with the geopolymerization products. Thus, the geopolymerization promotion was not obvious.

${ }^{29} \mathrm{Si}$ NMR spectra of kaolin, metakaolin and reaction products of both the KGP and $\mathrm{rGO} / \mathrm{KGP}$ formed at various reaction times are given in Fig. 8, 9 and Table 2. The ${ }^{29} \mathrm{Si}$ MAS NMR spectrum of raw kaolin consists of a single resonance centered at $-92.4 \mathrm{ppm}$ assigned to $\mathrm{Si}-\mathrm{O}-\mathrm{Si}$ linkages only (Fig. 8(a)). ${ }^{42}$ According to previous studies of aluminosilicate materials, ${ }^{29,30,32}$ the broad ${ }^{29} \mathrm{Si}$ NMR spectra peak could be divided into five possible silicon $\mathrm{Q}_{4}(\mathrm{mAl})$ species. Two peaks at -99.3 and $-90.8 \mathrm{ppm}$ correspond to tetra-coordinated $\mathrm{Si}$ atom, $\left(\mathrm{Q}_{4}(1 \mathrm{Al})\right.$ and $\left.\mathrm{Q}_{4}(3 \mathrm{Al})\right) \cdot \mathrm{Q}_{4}(1 \mathrm{Al})$ is the major species in the metakaolin (Fig. 8(b)).
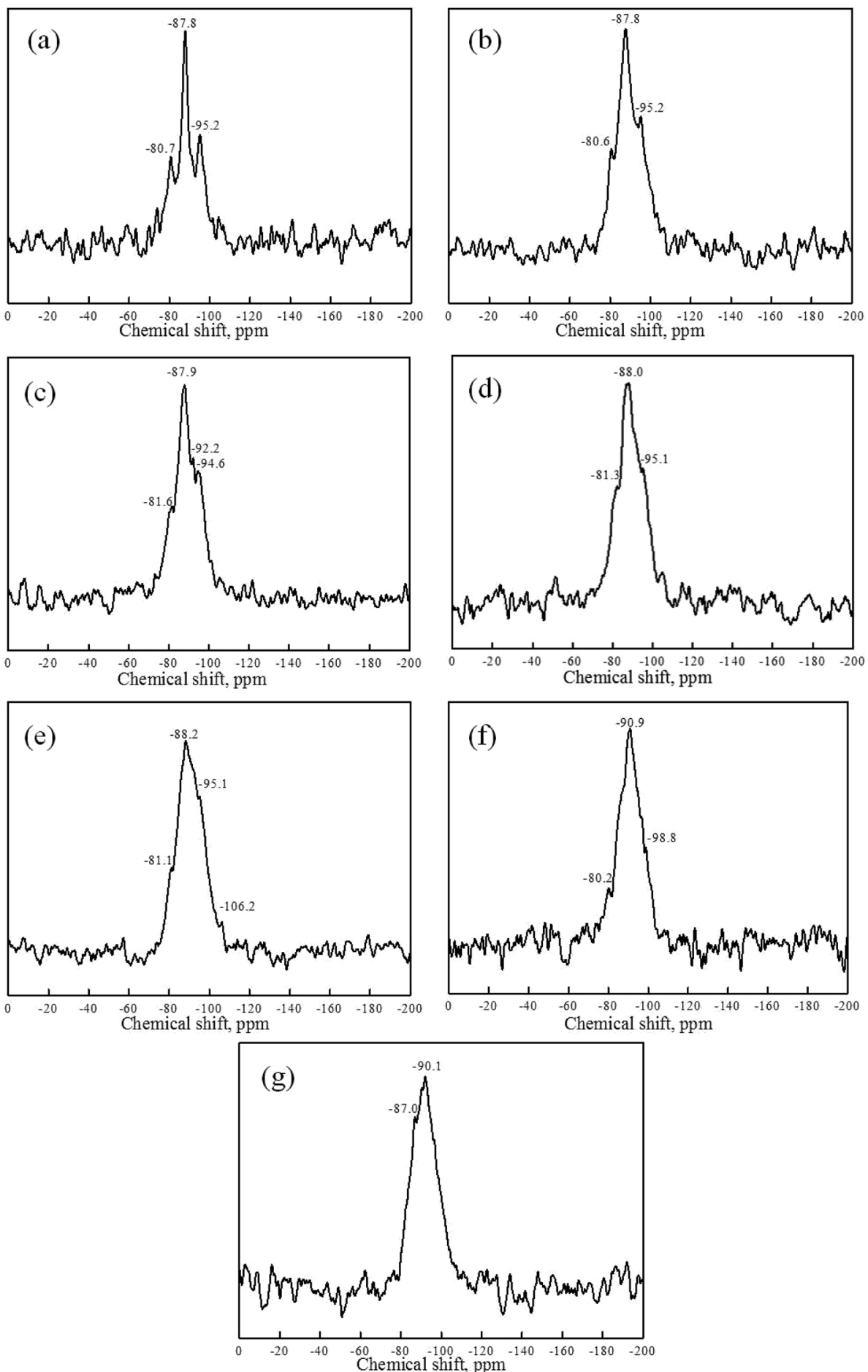

Fig. $9{ }^{29} \mathrm{Si}$ NMR spectras of reaction product of $\mathrm{rGO} / \mathrm{KGP}$ formed at various reaction times in geopolymerization process: (a)-(g) corresponding 0 min, 30 min, 1 h, 2 h, 3 h, 6 h and 24 h, respectively. 
On initiation of geopolymerization of KGP (Fig. 8(c)), the ${ }^{29} \mathrm{Si}$ NMR spectra shifts and two ${ }^{29} \mathrm{Si}$ resonances at -79.9 and $-87.6 \mathrm{ppm}$ appear, assigned to $\mathrm{Q}_{4}(4 \mathrm{Al})$ and $\mathrm{Q}_{4}(3 \mathrm{Al})$ structure units. Three peaks at $-80.7,-87.8$ and $-95.2 \mathrm{ppm}$ are seen for the $\mathrm{rGO} / \mathrm{KGP}$ products, which were assigned to Q4(4Al), Q4(3Al) and Q4(2Al), respectively (Fig. 9(a)). After $30 \mathrm{~min}$, three peaks at

Table $2{ }^{29} \mathrm{Si}$ NMR spectra results of reaction products formed at various reaction times

\begin{tabular}{|c|c|c|c|c|}
\hline Sample & & $\begin{array}{l}\text { mical shift } \\
\text { n) }\end{array}$ & & $\begin{array}{l}\text { ordination } \\
\text { Si atom }\end{array}$ \\
\hline \multirow[t]{2}{*}{ MK } & \multicolumn{2}{|c|}{$\begin{array}{l}-90.8 \\
-99.3\end{array}$} & \multicolumn{2}{|c|}{$\begin{array}{l}\mathrm{Q}_{4}(3 \mathrm{Al}) \\
\mathrm{Q}_{4}(1 \mathrm{Al})\end{array}$} \\
\hline & KGP & rGO/KGP & KGP & $\mathrm{rGO} / \mathrm{KGP}$ \\
\hline \multirow[t]{3}{*}{$0 \mathrm{~min}$} & -79.7 & -80.7 & $\mathrm{Q}_{4}(4 \mathrm{Al})$ & $\mathrm{Q}_{4}(4 \mathrm{Al})$ \\
\hline & -87.6 & -87.8 & $\mathrm{Q}_{4}(3 \mathrm{Al})$ & $\mathrm{Q}_{4}(3 \mathrm{Al})$ \\
\hline & - & -95.2 & - & $\mathrm{Q}_{4}(2 \mathrm{Al})$ \\
\hline \multirow[t]{3}{*}{$30 \mathrm{~min}$} & -79.7 & -80.6 & $\mathrm{Q}_{4}(4 \mathrm{Al})$ & $\mathrm{Q}_{4}(4 \mathrm{Al})$ \\
\hline & -87.4 & -87.8 & $\mathrm{Q}_{4}(3 \mathrm{Al})$ & $\mathrm{Q}_{4}(3 \mathrm{Al})$ \\
\hline & -93.7 & -95.2 & $\mathrm{Q}_{4}(2 \mathrm{Al})$ & $\mathrm{Q}_{4}(2 \mathrm{Al})$ \\
\hline \multirow[t]{4}{*}{$1 \mathrm{~h}$} & -80.6 & -81.6 & $\mathrm{Q}_{4}(4 \mathrm{Al})$ & $\mathrm{Q}_{4}(4 \mathrm{Al})$ \\
\hline & -87.6 & -87.9 & $\mathrm{Q}_{4}(3 \mathrm{Al})$ & $\mathrm{Q}_{4}(3 \mathrm{Al})$ \\
\hline & -93.9 & -92.2 & $\mathrm{Q}_{4}(2 \mathrm{Al})$ & $\mathrm{Q}_{4}(2 \mathrm{Al})$ \\
\hline & - & -94.6 & - & $\mathrm{Q}_{4}(2 \mathrm{Al})$ \\
\hline \multirow[t]{3}{*}{$2 \mathrm{~h}$} & -80.8 & -81.3 & $\mathrm{Q}_{4}(4 \mathrm{Al})$ & $\mathrm{Q}_{4}(4 \mathrm{Al})$ \\
\hline & -87.6 & -88.0 & $\mathrm{Q}_{4}(3 \mathrm{Al})$ & $\mathrm{Q}_{4}(3 \mathrm{Al})$ \\
\hline & -94.8 & -95.1 & $\mathrm{Q}_{4}(2 \mathrm{Al})$ & $\mathrm{Q}_{4}(2 \mathrm{Al})$ \\
\hline \multirow[t]{4}{*}{$3 \mathrm{~h}$} & -81.2 & -81.1 & $\mathrm{Q}_{4}(4 \mathrm{Al})$ & $\mathrm{Q}_{4}(4 \mathrm{Al})$ \\
\hline & -87.6 & -88.2 & $\mathrm{Q}_{4}(3 \mathrm{Al})$ & $\mathrm{Q}_{4}(3 \mathrm{Al})$ \\
\hline & -95.1 & -95.1 & $\mathrm{Q}_{4}(2 \mathrm{Al})$ & $\mathrm{Q}_{4}(2 \mathrm{Al})$ \\
\hline & - & -106.2 & - & $\mathrm{Q}_{4}(1 \mathrm{Al})$ \\
\hline \multirow[t]{3}{*}{$6 \mathrm{~h}$} & - & -80.2 & - & $\mathrm{Q}_{4}(4 \mathrm{Al})$ \\
\hline & -90.1 & -90.9 & $\mathrm{Q}_{4}(3 \mathrm{Al})$ & $\mathrm{Q}_{4}(3 \mathrm{Al})$ \\
\hline & -102.6 & -98.8 & $\mathrm{Q}_{4}(1 \mathrm{Al})$ & $\mathrm{Q}_{4}(1 \mathrm{Al})$ \\
\hline \multirow[t]{2}{*}{$24 \mathrm{~h}$} & - & -87.0 & - & $\mathrm{Q}_{4}(3 \mathrm{Al})$ \\
\hline & -90.1 & -90.1 & $\mathrm{Q}_{4}(3 \mathrm{Al})$ & $\mathrm{Q}_{4}(3 \mathrm{Al})$ \\
\hline
\end{tabular}

$-79.7,-87.4$ and $-93.7 \mathrm{ppm}$ (or $-80.6,-87.8$ and $-95.2 \mathrm{ppm}$ ) were seen indicating the coordination of $\mathrm{Q}_{4}(4 \mathrm{Al}), \mathrm{Q}_{4}(3 \mathrm{Al})$ and a new $\mathrm{Q}_{4}(2 \mathrm{Al}$ ) species in the KGP (Fig. 8(d)) (or rGO/KGP (Fig. 9(b)). The ${ }^{29} \mathrm{Si}$ chemical shifts of the KGP products showed no obvious change within 1-2 h, while the relative intensity of $-80.6 \mathrm{ppm}$ increased regularly (Fig. 8(e) and (f)). The peaks shift to lower position coincident with increases in $\mathrm{Si}-\mathrm{O}-\mathrm{Al}$ species forming. As the reaction progress, $\mathrm{Q}_{4}(1 \mathrm{Al})$ appear at $-106.2 \mathrm{ppm}$ in the $\mathrm{rGO} / \mathrm{KGP}$ samples when the reaction came to $3 \mathrm{~h}$ (Fig. 9(e)). At $6 \mathrm{~h}$ in the rGO/KGP products (Fig. 9(f)), ${ }^{29} \mathrm{Si}$ resonances at $-80.2,-90.9$ and $-98.8 \mathrm{ppm}$, assigned to $\mathrm{Q}_{4}(4 \mathrm{Al}), \mathrm{Q}_{4}(3 \mathrm{Al})$ and $\mathrm{Q}_{4}(1 \mathrm{Al})$ species appear, respectively.

However, after $24 \mathrm{~h}$, only one broad ${ }^{29} \mathrm{Si}$ NMR peak of KGP at $-90.1 \mathrm{ppm}$ is seen (Fig. 8(i)). The peaks at -87.0 and $-90.1 \mathrm{ppm}$ of $\mathrm{rGO} / \mathrm{KGP}$ are observed (Fig. $9(\mathrm{~g})$ ), indicating that $\mathrm{Si}$ is present mainly as $\mathrm{Q}_{4}(3 \mathrm{Al})$ structural units. Compared with the pure $\mathrm{KGP}$, the addition of rGO accelerated the conversion of $\mathrm{Si}$ structure unit from $\mathrm{Q}_{4}(1 \mathrm{Al})$ to $\mathrm{Q}_{4}(4 \mathrm{Al}), \mathrm{Q}_{4}(3 \mathrm{Al}), \mathrm{Q}_{4}(2 \mathrm{Al})$ and $\mathrm{Q}_{4}(1 \mathrm{Al})$ species. Thus, the addition of rGO affects the Si structure during the geopolymerization and has an positive influence on the generation of $\mathrm{Q}_{4}(3 \mathrm{Al})$ species.

To sum up, the effects of GO on the geopolymerization of the rGO/KGP could be illustrated in Fig. 10. For the KGP (Fig. 10(a)), the geopolymerization mechanism can be rationally expressed according to the experimental analysis as follows. First, metakaolin particles dissolve from the surface after mixing with alkaline silicate solutions; the $\mathrm{Si}-\mathrm{O}$ bond and $\mathrm{Al}-\mathrm{O}$ bond hydrolyze; Si and Al monomers diffuse; polycondense and rearrange; five and six coordinate $\mathrm{Al}-\mathrm{O}$ sites convert to four coordination, condensing Si species with Al species mainly in the form of $\mathrm{Q}_{4}(3 \mathrm{Al})$ and $\mathrm{Al}$ in four coordinate.

GO can be in situ reduced to rGO in alkaline silicate solutions and have positive effects on the geopolymerization during the reaction process. ${ }^{22}$ As described in Fig. $10(\mathrm{~b})$, the rGO accelerates the conversion of $\mathrm{Al}-\mathrm{O}$ sites into four coordinates and $\mathrm{Si}$ atoms in the form of $\mathrm{Q}_{4}(3 \mathrm{Al})$, but has not changed the final
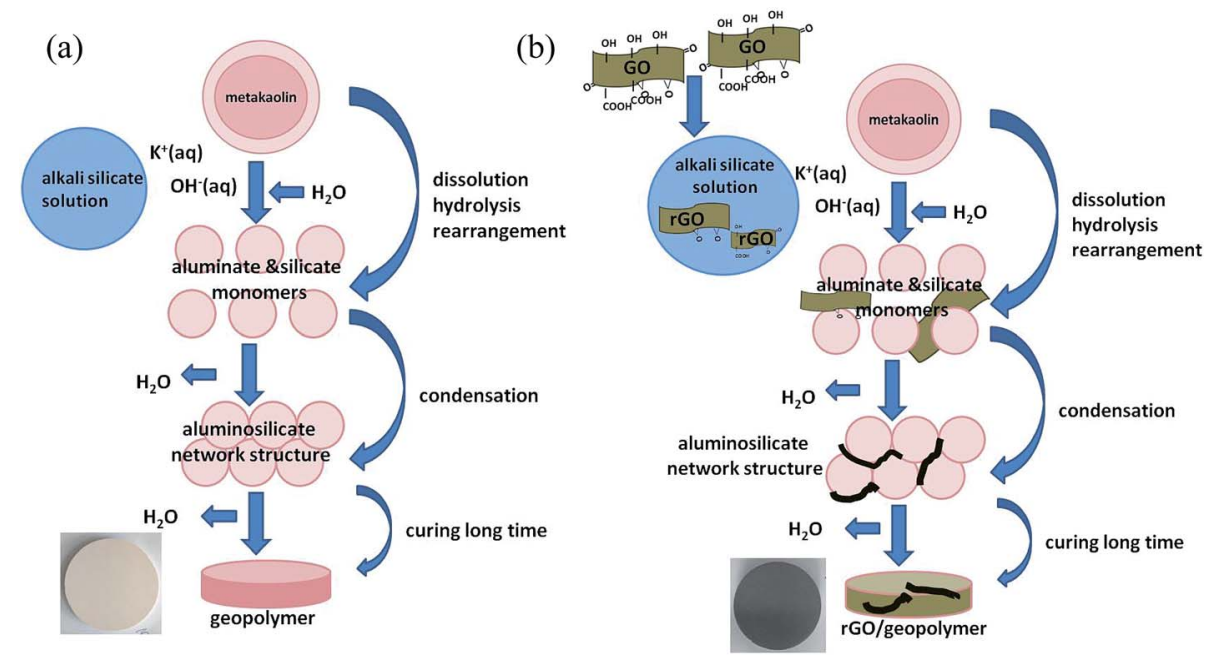

Fig. 10 Schematic diagram of geopolymerization of (a) KGP and (b) rGO/KGP. 
network structure of the $\mathrm{rGO} / \mathrm{KGP}$. The reaction products bond well with the rGO sheets and show denser microstructure and lower amorphous degree with the increased in reaction time. Based on the above analyses, the addition of GO is proper in preparing $\mathrm{rGO} / \mathrm{KGP}$ composites. Meanwhile, the presence of rGO contributed to the enhancement of mechanical performance of geopolymer. As reported in our previous studies, ${ }^{\mathbf{2 3 , 2 4}}$ compared with pure geopolymer, improvements in mechanical properties were achieved through rGO reinforcement of 0.05-1 $\mathrm{wt} \%$ at room temperature. With $1 \mathrm{wt} \% \mathrm{GO}$ addition, the fracture toughness and flexural strength of $\mathrm{rGO} / \mathrm{g}$ eopolymer composites increased by approximately $30 \%$ and $7 \%$, respectively, attributing to the proper interface bonding, crack deflection and propagation and rGO pull-out.

\section{Conclusions}

In the present study, the method to stop geopolymerization reaction was provided and the effects of graphene oxide on the geopolymerization mechanism of geopolymer based on natural metakaolin were investigated systematically.

(1) The reaction products of KGP and rGO/KGP in the geopolymerization process ( $0-24 \mathrm{~h}$ ) can be isolated by introducing ethanol/acetone mixtures. The voids in the reaction products decrease significantly with the geopolymerization time. The products display typical broad amorphous humps around 17$32^{\circ} 2 \theta$ and the amorphous degree decrease with the reaction time.

(2) During geopolymerization, the metakaolin dissolved in the alkaline silicate solutions, and $\mathrm{Si}-\mathrm{O}$ bond and $\mathrm{Al}-\mathrm{O}$ bond hydrolyzed, five and six coordinates of $\mathrm{Al}-\mathrm{O}$ sites converted into four coordinates, condensing the network structure in which $\mathrm{Si}$ mainly in the form of $\mathrm{Q}_{4}(3 \mathrm{Al})$ and $\mathrm{Al}$ in four coordinate.

(3) The addition of GO accelerated the conversion of $\mathrm{Al}-\mathrm{O}$ sites into four coordinates and $\mathrm{Si}$ atoms in the form of $\mathrm{Q}_{4}(3 \mathrm{Al})$. The reaction products of geopolymer matrix bonded well with the rGO sheets and showed denser microstructure and lower amorphous degree with the increase in reaction time.

\section{Acknowledgements}

This work was supported by the National Natural Science Foundation of China (NSFC No. 51502052, 51402068, 51372048, 51321061, 51225203) and Fundamental Research Funds for the Central Universities (Grant No. HIT. NSRIF. 20165). We would like to thank Dr Richard M. Laine (University of Michigan, USA) for the help with science and language.

\section{References}

$1 \mathrm{~J}$. Davidovits, Geopolymers and geopolymeric materials, $J$. Therm. Anal., 1989, 35, 429-441.

2 J. Davidovits, 30 Years of Successes and Failures in Geopolymer Applications. Market: Trends and Potential Breakthroughs, Geopolymer Conference, 2002, vol. 10, pp. 1-16.

3 W. K. Part, M. Ramli and C. B. Cheah, An overview on the influence of various factors on the properties of geopolymer concrete derived from industrial by-products, Construct. Build. Mater., 2015, 77, 370-395.

4 M. B. M. Salahuddin, M. Norkhairunnisa and F. Mustapha, A review on thermophysical evaluation of alkali-activated geopolymers, Ceram. Int., 2015, 41, 4273-4281.

$5 \mathrm{~J}$. L. Provis, Geopolymers and other alkali activated materials: why, how, and what?, Mater. Struct., 2014, 47, 11-25.

6 P. Duxson, J. L. Provis, G. C. Lukey, et al., Understanding the relationship between geopolymer composition, microstructure and mechanical properties, Colloids Surf., A, 2005, 269, 47-58.

7 J. Tailby and K. J. D. MacKenzie, Structure and mechanical properties of aluminosilicate geopolymer composites with Portland cement and its constituent minerals, Cem. Concr. Res., 2010, 40, 787-794.

8 P. He, D. Jia, T. Lin, et al., Effects of high-temperature heat treatment on the mechanical properties of unidirectional carbon fiber reinforced geopolymer composites, Ceram. Int., 2010, 36, 1447-1453.

9 T. S. Lin, D. C. Jia, P. G. He, et al., Thermo-mechanical and Microstructural Characterization of Geopolymers with $\alpha$ $\mathrm{Al}_{2} \mathrm{O}_{3}$ Particle Filler, Int. J. Thermophys., 2009, 30, 1568-1577.

10 T. Kovárík, L. Kullová and D. Rieger, Production of refractory chamotte particle-reinforced geopolymer composite, IOP Conf. Ser.: Mater. Sci. Eng., 2016, 123, 012041.

11 T. Alomayri, F. U. A. Shaikh and I. M. Low, Synthesis and Mechanical Properties of Cotton Fabric Reinforced Geopolymer Composites, Composites, Part B, 2014, 60, 36-42.

12 T. S. Lin, D. C. Jia, P. G. He, et al., Effects of fiber length on mechanical properties and fracture behavior of short carbon fiber reinforced geopolymer matrix composites, Mater. Sci. Eng., A, 2008, 497, 181-185.

13 T. S. Lin, D. C. Jia, M. R. Wang, et al., Effects of fibre content on mechanical properties and fracture behaviour of short carbon fibre reinforced geopolymer matrix composites, Bull. Mater. Sci., 2009, 32, 77-81.

14 P. Timakul, W. Rattanaprasit and P. Aungkavattana, Improving compressive strength of fly ash-based geopolymer composites by basalt fibers addition, Ceram. Int., 2016, 42, 6288-6295.

15 A. K. Geim and K. s. Novoselov, The rise of graphene, Nat. Mater., 2007, 6, 183-191.

16 A. H. C. Neto, F. Guinea, N. M. R. Peres, et al., The electronic properties of graphene, Rev. Mod. Phys., 2009, 81, 109.

17 W. Choi, I. Lahiri, R. Seelaboyina, et al., Synthesis of graphene and its applications: a review, Crit. Rev. Solid State Mater. Sci., 2010, 35, 52-71.

18 S. Stankovich, D. A. Dikin, G. H. B. Dommett, et al., Graphene-based composite materials, Nature, 2006, 442, 282-286.

19 J. Du and H. M. Cheng, The fabrication, properties, and uses of graphene/polymer composites, Macromol. Chem. Phys., 2012, 213, 1060-1077.

20 H. Porwal, S. Grasso and M. J. Reece, Review of grapheneceramic matrix composites, Adv. Appl. Ceram., 2013, 112, 443-454. 
21 M. R. Wang, D. C. Jia, P. G. He, et al., Microstructural and mechanical characterization of fly ash cenosphere/ metakaolin-based geopolymeric composites, Ceram. Int., 2011, 37, 1661-1666.

22 S. Yan, P. He, D. Jia, et al., In situ fabrication and characterization of graphene/geopolymer composites, Ceram. Int., 2015, 41, 11242-11250.

23 S. Yan, P. He, D. Jia, et al., Effect of reduced graphene oxide content on the microstructure and mechanical properties of graphene-geopolymer nanocomposites, Ceram. Int., 2016, 42, 752-758.

24 S. Yan, P. He, D. Jia, et al., In Situ Processing of Graphene/ Leucite Nanocomposite Through Graphene Oxide/ Geopolymer, J. Am. Ceram. Soc., 2016, 99, 1164-1173.

25 S. Yan, P. He, D. Jia, et al., In situ preparation of fully stabilized graphene/cubic-leucite composite through graphene oxide/geopolymer, Mater. Des., 2016, 101, 301-308.

$26 \mathrm{H}$. Xu and J. S. J. Van Deventer, The geopolymerisation of alumino-silicate minerals, Int. J. Miner. Process., 2000, 59, 247-266.

27 H. Xu and J. S. J. Van Deventer, Ab initio calculations on the five-membered alumino-silicate framework rings model: implications for dissolution in alkaline solutions, Comput. Chem., 2000, 24, 391-404.

28 C. E. White, J. L. Provis, T. Proffen, et al., Molecular mechanisms responsible for the structural changes occurring during geopolymerization: multiscale simulation, AIChE J., 2012, 58, 2241-2253.

29 L. Weng and K. Sagoe-Crentsil, Dissolution processes, hydrolysis and condensation reactions during geopolymer synthesis: Part I-Low Si/Al ratio systems, J. Mater. Sci., 2007, 42, 2997-3006.

30 K. Sagoe-Crentsil and L. Weng, Dissolution processes, hydrolysis and condensation reactions during geopolymer synthesis: Part II. High Si/Al ratio systems, J. Mater. Sci., 2007, 42, 3007-3014.
31 X. Chen, A. Meawad and L. J. Struble, Method to Stop Geopolymer Reaction, J. Am. Ceram. Soc., 2014, 97, 32703275.

32 P. Duxson, A. Fernández-Jiménez, J. L. Provis, et al., Geopolymer technology: the current state of the art, $J$. Mater. Sci., 2007, 42, 2917-2933.

33 E. Knapen, O. Cizer, K. Van Balen, et al., Effect of free water removal from early-age hydrated cement pastes on thermal analysis, Construct. Build. Mater., 2009, 23, 3431-3438.

34 L. D. Mitchell and J. C. Margeson, The effects of solvents on $\mathrm{C}-\mathrm{S}-\mathrm{H}$ as determined by thermal analysis, J. Therm. Anal. Calorim., 2006, 86, 591-594.

35 P. He, D. Jia, M. Wang, et al., Thermal evolution and crystallization kinetics of potassium-based geopolymer, Ceram. Int., 2011, 37, 59-63.

36 T. Lin, D. Jia, P. He, et al., Thermal-mechanical properties of short carbon fiber reinforced geopolymer matrix composites subjected to thermal load, J. Cent. South Univ. Technol., 2009, 16, 881-886.

37 C. T. Johnston, J. E. Kogel, D. L. Bish, et al., Low-temperature FTIR study of kaolin-group minerals, Clays Clay Miner., 2008, 56, 470-485.

38 R. L. Frost, The structure of the kaolinite minerals; a FTRaman study, Clay Miner., 1997, 32, 65-77.

39 D. Akolekar, A. Chaffee and R. F. Howe, The transformation of kaolin to low-silica X zeolite, Zeolites, 1997, 19, 359-365.

$40 \mathrm{H}$. Wang, H. Li and F. Yan, Synthesis and mechanical properties of metakaolinite-based geopolymer, Colloids Surf., A, 2005, 268, 1-6.

41 G. M. Nasab, F. Golestanifard and K. J. D. MacKenzie, The Effect of the $\mathrm{SiO}_{2} / \mathrm{Na}_{2} \mathrm{O}$ Ratio in the Structural Modification of Metakaolin-Based Geopolymers Studied by XRD, FTIR and MAS-NMR, Journal of Ceramic Science and Technology, 2014, 5, 185-192.

42 H. Yang, M. Liu and J. Ouyang, Novel synthesis and characterization of nanosized $\gamma-\mathrm{Al}_{2} \mathrm{O}_{3}$ from kaolin, Appl. Clay Sci., 2010, 47, 438-443. 